\title{
アミン処理によるポリエステル繊維 の親水化について
}

\author{
富山大学教育学部 松川三郎・島 康子・石原ミキ \\ 福井大学工学部 桜井謙資
}

\section{AMINOLYSIS OF POLY(ETHYLENE TEREPHTHALATE) FIBERS TO IMPART THE HYDROPHILICITY ${ }^{* 1}$}

\author{
By Saburo Matsukawa, Yasuko Shima, Kensuke Sakurai ${ }^{\bullet 2}$ \\ and Miki Ishihara \\ (Faculty of Education, Toyama University, Gofuku, \\ Toyama-shi, Toyama, Japan) \\ *2 (Faculty of Engineering, Fukui University, Bunkyo, \\ Fukui-shi, Fukui, Japan)
}

Polyester fabrics were aminolyzed with hydrazine hydrate. It was confirmed that the hydrazine reacted with polyesters from the dyeing test using an acid dye. The moisture regain of aminolyzed fibers increased with increasing the crystallinity of fibers. It was suggested that the aminolysisreaction mainly took place in the intermediate region surrounding the crystallites, and in the disordered portion of crystal. This leads to increase the accessibility of moisture to the surfaces of crystallites; bringing about the increase of moisture regain.

(Received March 22, 1985)

\section{1. 緒言}

ポリエステル繊稚が衣服に使用されるとき最大の欠点 は，その親水性が小さいととにあるととは周知の事夷で ある。合成緎維に吸湿性，吸水性を付与する方法は荒井 の分類のようにポリマー自体の漞水化，後加工に上る織 維表面の親水化，お上び纎維自身を多孔質にする方法の 三つの方法に上るものであるう。

和田ら ${ }^{2)}$ はポりエステル繊維を多孔質にした場合の吸 水性の変化と我服の着心地との関係を調へている。一方, 見在非常に多く行われている後加工の一つにポリエステ ルのアルカリ減量加工がある。この加工に関連して山崎

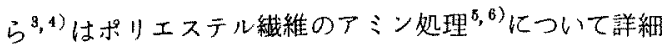
に研究し、アミンの種類によって微細構造中の反応にあ

*1乙の報文を「湿潤衣服の保温性に関する研究（第 1 報), Studies on the thermal insulation of the wet clothes (Part 1) 」とする。
ずかる頒域に差異のあるととを示した。また，アミン処 理が現在は繊維の構造研究の手段に用いられているか， 罗来さらに事用的な使用比発展するであるうことを示晙

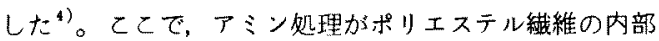
にまで漫透するととと， アミン分解反応物にアミ，基が 付与されることから，䋱維内部まで漞水化されたポリエ ステル䄉維を得ることが期待される。

本研究では，湿閏時の衣服の保温性に関する研究の一 相として，織物の組織に大きな变化を与えすに親水性を 大きく変える观理の一つとしてこのアミン処理を用いた。 さらにこの場合，瀻維の親水化機棈を明らかにするため に潋細構造の变化に関する情報を得ようとした。

\section{2. 実験方法}

\section{1 試料布および試薬}

試料布はポリエスデタフタ $75 \mathrm{~d} \times 75 \mathrm{~d} / 210 \times 191(5$ $\mathrm{cm}$ )の実験用白生地（関西衣生活研究所）を用いた。 
ン分解にはヒドラジンヒドラートの一級試楽を，また， 溶媒には水およびメタノールの一級試薬を用いた。姏理 布の酸性染料による染色にはC.I.Acid Blue 3 の市販品 を用いた。

\section{2 処理方法および測定方法}

\subsubsection{Tミン処理方法}

ポリエステルタフタ $30 \mathrm{~cm} \times 30 \mathrm{~cm} 1$ 枚につき所定濃 度のヒドラジン水溶液またはメタノール溶液 1 l存意 し, $20 \pm 0.5^{\circ} \mathrm{C}$ の恒温室内で所定時間浸漬し，その後流 水で 3 時間洗净，さらにエタ/一ルで数回洗浄して風乾 した。

\subsection{2 染色方法}

上記の酸性染料を用い，対物濃度 $3 \%$ ，芒硝 $20 \%, 35$

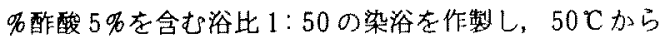
徐々に昇温し，85 90゚で 30 分間染色した。染色後充 分水洗し， $60 \mathrm{C}$ で乾燥した。

\section{2 .3 水分率测定}

$65 \pm 2 \%$ R.H., $20 \pm 0.5^{\circ} \mathrm{C}$ の恒温恒湿窒内に 48 時間静 犆した試料の絶乾重量に対する重量增加分を $65 \%$ R.H. 儿おける水分率 (\%) しした。また，95\% R.H，での水分 率測定のためにはリン酸水素二ナトリウム飽和水溶液老

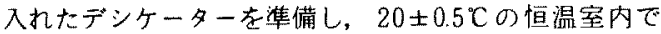
65\% R.H，の場合上同様にして測定した。なお，絶乾重

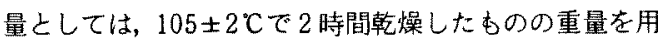
いた。

\section{2 .4 透湿率測定}

直径が大略等しい $200 \mathrm{ml}$ のビーカーに上緣から約 1 $\mathrm{cm}$ までの水を入れ，測定用試料布で覆って，上記恒温 恒湿室内に 24 時間静置した後，水の重量减をパーセン トで表した。

\subsection{5 反射率測定}

染色されたアミン好理布の染色濃度を比較する目的で 染色布の反射率を测定した。測定には光笔反射計（日立 製作所製，SPR-2 型）在用い，表・裏各 3 回の測定值 の平均をあって試料布の反射率とした。

\subsection{6 比重測定书上び結晶化度の算出}

四塩化炭素と $n$ ーヘプタンの混合液を用い， $30 \pm 0.5^{\circ} \mathrm{C}$ で沈法”゙より測定した。用いた四塩化宸素の比重は $1.598 \sim 1.608 \mathrm{~g} / \mathrm{cm}^{3}, n$-ヘプタンの比重は $0.683 \sim 0.685$ $\mathrm{g} / \mathrm{cm}^{3}$ であった。なお，試料の比重と同一となった混含 液の比重はピクノメーターにより別途測定した。結晶化 度 $x$ は密度 $d$ から次式化よって算出しだ。

$$
1 / d=x / d_{\mathrm{c}}+(1-x) / d_{\mathrm{a}}
$$

ここで, $d_{\mathrm{c}}=1.455, d_{\mathrm{a}}=1.335$ はそれぞれポリエステ ルの結晶および非晶の密度である゙ 。

\subsubsection{X線測定}

底角 X 線回折強度曲線は理学電㙨紫 D-IA型 X 線発生 装置, ゴニオメーター，試料台，シンチレーションカウ ンターを用いて得た。照射X線は $40 \mathrm{kV}, 20 \mathrm{~mA}, \mathrm{Nj}$ フ イルターろ過 $\mathrm{CuK}_{\alpha}$ 線を用いた。赤道扰よび子午線上の 强度曲線を测定した。結晶の面間隔 $(d)$ は Braggの式か ら，また，結晶サイス゚ $(D)$ は Sherrerの式から求めた。

\section{3. 結果と考察}

\section{1 重眭減少と比重・結晶化度の变化}

ポリエステル瀻維は上ドラシンによりアミン分解され, 低分子量になった部分から溶解し，系外に除かれる。処 理条件之重量减少率の関係を表 1 に示した。ヒドラジン のメタノール溶液は水溶液に比へて分解速度が著しく速 いことは山㱦ら゙う報告にあみられた通りである。しか も，分解時間または，アミン濃度の增加による重量の減 少率は一定時間または一定濃度で急激に增加する傾向が みられた。これについては，後の染色試験の項で検討す る。つぎにアミン処理による比重の変化を表 2 に示した。 いずれの場合も未処理試料より高い密度を示している。 メ夕ノール溶液と水溶液では処理により同程度の重量活 少を示す試料であメ夕ノール溶液処理の万が比重の增加 が大きいという傾问がられる。メタノール溶液が水溶

Table 1 Weight loss of PET-fibers by the treatment with hydrazine hydrate

\begin{tabular}{|c|c|c|c|}
\hline \multirow{2}{*}{$\begin{array}{l}\text { Solvent : } \\
\text { Treating time (hr) }\end{array}$} & \multicolumn{3}{|c|}{ Concentration of H.H. (\$) } \\
\hline & 10 & 30 & 50 \\
\hline \multicolumn{4}{|l|}{ Methanol } \\
\hline 1 & 0.02 & 0.41 & 0.63 \\
\hline 2 & - & 0.24 & 5.25 \\
\hline 3 & 0.61 & 0.35 & 24.84 \\
\hline \multicolumn{4}{|l|}{ Water } \\
\hline 18 & 0.02 & 0.05 & 0.48 \\
\hline 30 & 0.43 & 0.46 & 0.71 \\
\hline 42 & 0.29 & - & 24.29 \\
\hline
\end{tabular}

Table 2 Changes in density of PET-fibers treated with hydrazine hydrate

\begin{tabular}{|c|c|c|c|}
\hline \multirow{2}{*}{$\begin{array}{l}\text { Solvent: } \\
\text { Treating time }(\mathrm{hr})\end{array}$} & \multicolumn{3}{|c|}{ Concentration of H.H. (\$) } \\
\hline & 10 & 30 & 50 \\
\hline \multicolumn{4}{|l|}{ Methanol } \\
\hline 1 & 1.4010 & 1.4088 & 1.4105 \\
\hline 2 & 1.4053 & 1.4072 & 1.4169 \\
\hline 3 & 1.4066 & 1.4149 & 1.4313 \\
\hline \multicolumn{4}{|l|}{ Water } \\
\hline 18 & 1.4003 & 1.4038 & 1.4095 \\
\hline 30 & 1.4008 & 1.4058 & 1.4132 \\
\hline 42 & 1.4053 & 1.4091 & 1.4151 \\
\hline
\end{tabular}

(untreated, 1.3974) 
Table 3 Changes in crystallinity of PET-fibers treated with hydrazine hydrate

\begin{tabular}{|c|c|c|c|}
\hline \multirow{2}{*}{$\begin{array}{l}\text { Solvent: } \\
\text { Treating time }(h r)\end{array}$} & \multicolumn{3}{|c|}{ Concentration of H.H. (og) } \\
\hline & 10 & 30 & 50 \\
\hline \multicolumn{4}{|l|}{ Methanol } \\
\hline 1 & 0.57 & 0.64 & 0.65 \\
\hline 2 & 0.61 & 0.62 & 0.70 \\
\hline 3 & 0.62 & 0.68 & 0.82 \\
\hline \multicolumn{4}{|l|}{ Water } \\
\hline 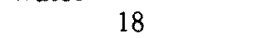 & 0.57 & 0.59 & 0.64 \\
\hline 30 & 0.57 & 0.61 & 0.67 \\
\hline 42 & 0.61 & 0.64 & 0.71 \\
\hline
\end{tabular}

(untreated, 0.54)

液よりまより内部に浸透し，より高オーダーの領域で分 解反応が行われることの他に，溶液中での再結晶や不完 全結晶領域の分解による結晶の完全化も考えられる。表 3は比重测定值から求めた結晶化度の値である。前表で 見られた傾向はさらに明瞭に現われている。

\section{2 吸湿性およひ透湿性}

相対湿度 $65 \%$ およひ 95\%での処理試料の水分率を結 晶化度に対してプロットしたあのが図1，図2である。 两図とも結晶化度の増加につれて水分率が増加するとい う現象がみられ，図2亿示されたように水分率の大きな ものでは6\%に近いものが得られた。このととは，一般 に認められている非晶領域での水分吸着のみでは説明出 来ず，中間領域や結晶表面への㠷着が増加すると考える ことが合理的と思加れるつぎに，吸湿性に関連した透 湿性の測定結果を図 3 に示した。結晶化度の增加につれ て透湿性が堌加する傎向がみられ，先きの吸湿性の変化 と良好に一致する結果が得られた。

この原因はむしろ巨視的な瀻維形態の変化の結果之考

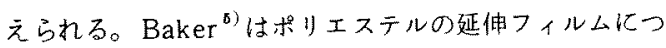

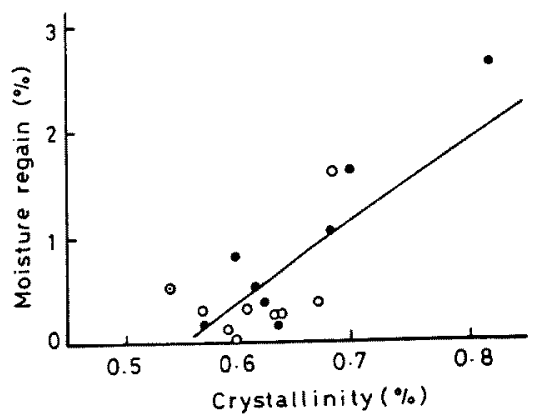

Fig. 1 Changes in moisture regain of polyester fabrics with crystallinities (at $65 \%$ R.H.)
$\odot$ untreated
treated with amine in water
- treated with amine in methanol

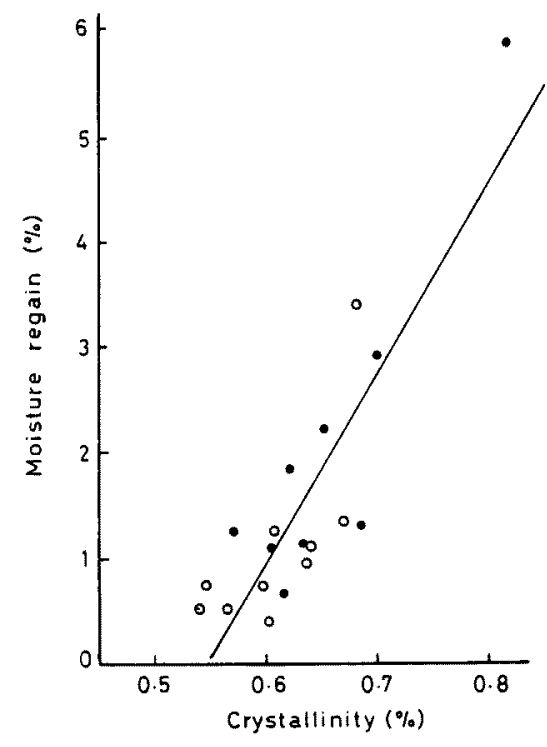

Fig. 2 Changes in moisture regain of polyester fabrics with crystallinities (at $95 \%$ R.H.)

$\odot$ untreated

$O$ treated with amine in water

- treated with amine in methanol

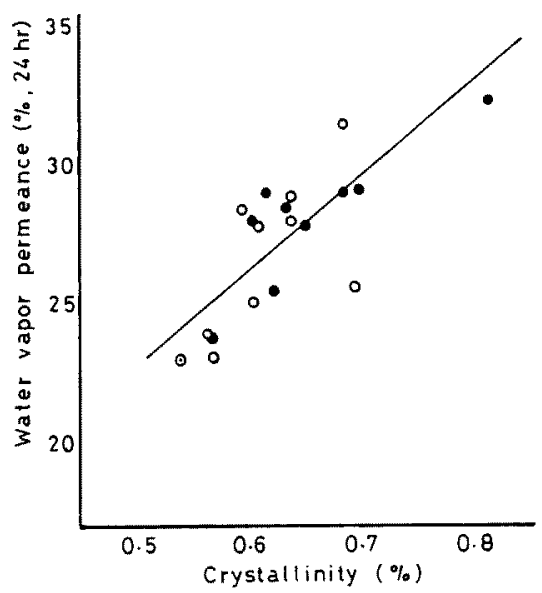

Fig. 3 Changes in water vapor permeability of polyester fabrics with crystallinities

$\odot$ untreated

0 treated with amine in water

- treated with amine in methanol 
いて，また山崎ら”は跂エステル䋐維についてアミン 处理により内部までクラックが形成されるととを観察し ている。すなわち，透湿性の增加に対しては，織物の若 干の収縮を伴う䄉維の細化ならびに，この様なクラック の形成などの影響が考えられる。

\section{3 染着性の変化}

染色布の反射率で表打した染着性の变化を図 4 亿示し た。反射係が小さい程濃色に染色されているととを示す あのであるが, 結昆化度との関係は水分率の変化の上う な直線的なものでなく，結晶化度の增加に対し染著量の

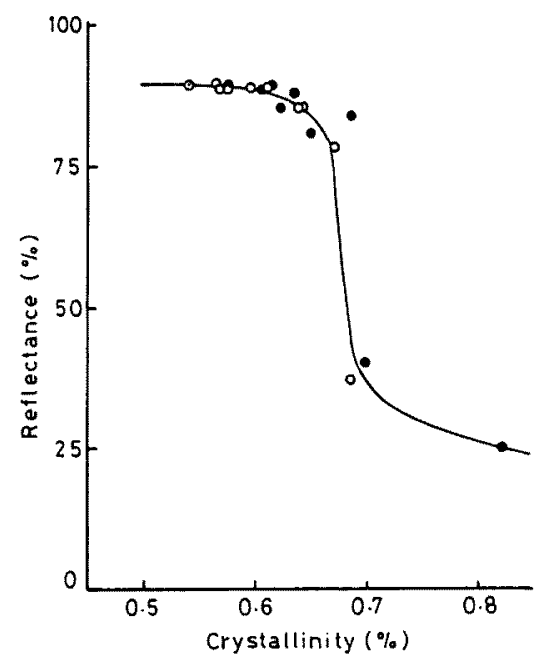

Fig. 4 Changes in reflectance of polyester fabrics with crystallinities
$\odot$ untreated
treated with amine in water
- treated with amine in methanol

不連続な增加がるられる。水分率の項で考察したように， アミン処理によって中間領域および結晶表面への吸着が 増加すると考元れば，染料の場合は中間領域の分解がか なり進行した時に結晶表面への吸着が始まるるのと推定 出来る。

\section{4 結晶領域の変化}

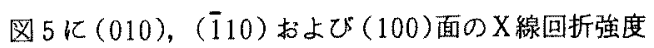
曲線を示した。波形分踓して求めた各面のピーク散乱角 と半洒幅加ら面間隔 $(d)$ および結晶サイズ $(D)$ を計算し た結果を表 4 に示した。興味あるこよはピーク散乱角(す なわち面間隔)にはほとんど変化がみられないのに対し， (010)面书よび(100)面の結晶サイズがメタノール溶液 処理により增大している点である。ての傾向は表 4 亿同 時に示されている織維軸方向の結晶サイズ $D$ - 05 であ同様 に現われた。半価幅の減少は結晶の完全化を反映するも のであるので,メタノール中のアミン処理は䋐維内部の 中間領域での反応之同時に，結晶中のみだれた部分まで 屯竹解除去し，結晶の完全化をうながするの考察し得 る。また，(110）面の半価幅の增大については，との面 に垂直な方向からのアミン分解が前三者に比へて容易で あれば結晶自体の浸食による紐化とも考えられ，とのとと は水溶液での非常に長時間の反応でも起り得ると考えら れるか，全体にかなり微妙な変化であるので，本実験の 範囲内では先きの $(010),(100)$ 扰よび(105) 面での傾 向をとらえた程度に上どまる。

\section{4. 結論}

ヒドラジンヒドラートを用いてポリエステル蟣維のア ミン処理を行い, 繊維の親水性の変化を敉細構造の変 化に関連づけて検討した。得られた結果はつぎのでとく

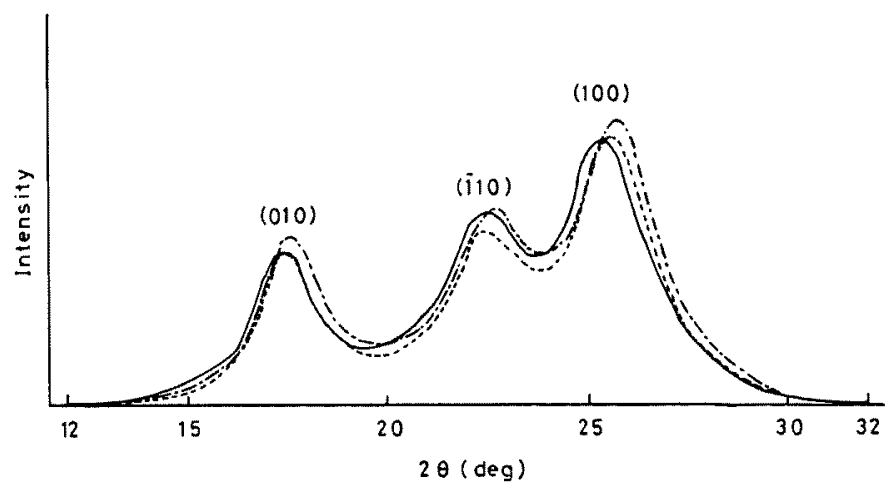

Fig. 5 Wide-angle X-ray diffraction curves of untreated- and amine-treated polyester fabrics. - untreated; - - - - treated with amine at concentration of $50 \%$ in methanol for $3 \mathrm{hrs}$; -...- treated with amine at concentration of $50 \%$ in water for $42 \mathrm{hrs}$ 
Table 4 The spacing and crystallite size in polyester treated with amine at concentration of $50 \%$ : in methanol for $3 \mathrm{hrs}$, in water for $42 \mathrm{hrs}$.

\begin{tabular}{|c|c|c|c|c|}
\hline $\begin{array}{l}\text { Plane: } \\
\text { Solvent }\end{array}$ & $\begin{array}{l}\text { Scattering angle } \\
2 \theta, \text { degree }\end{array}$ & $\begin{array}{c}\text { Spacing } \\
d, \AA \\
\end{array}$ & $\begin{array}{l}\text { Half - value width } \\
\qquad B(\mathrm{rad}) \times 100\end{array}$ & $\begin{array}{c}\text { Crystallite size } \\
D, \AA \\
\end{array}$ \\
\hline \multicolumn{5}{|l|}{$(010)$} \\
\hline untreated & 17.46 & 5.07 & 3.057 & 47.9 \\
\hline methanol & 17.58 & 5.04 & 2.857 & 51.3 \\
\hline water & 17.67 & 5.01 & 3.107 & 47.1 \\
\hline 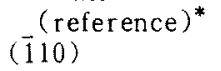 & $(17.42)$ & $(5.08)$ & & \\
\hline untr eated & 22.50 & 3.95 & 3.978 & 37.1 \\
\hline methanol & 22.52 & 3.94 & 4.195 & 35.2 \\
\hline water & 22.62 & 3.93 & 4.186 & 35.3 \\
\hline $\begin{array}{l}(\text { refer ence })^{*} \\
(100)\end{array}$ & $(22.54)$ & $(3.94)$ & & \\
\hline untr eated & 25.60 & 3.48 & 3.835 & 38.7 \\
\hline methanol & 25.84 & 3.44 & 3.768 & 39.4 \\
\hline water & 25.93 & 3.43 & 3.892 & 38.2 \\
\hline$\frac{(\text { reference })^{*}}{(105)}$ & $(25.57)$ & $(3.48)$ & & \\
\hline untreated & 43.0 & 2.10 & 2.271 & 68.5 \\
\hline methanol & 43.0 & 2.10 & 2.206 & 70.5 \\
\hline water & 43.1 & 2.10 & 2.260 & 68.9 \\
\hline$(\text { reference })^{*}$ & $(42.54)$ & $(2.12)$ & & \\
\hline
\end{tabular}

*: Daubeny's value ${ }^{8)}$

である。

1）アミン尔解反応は生成するアミノ基末端への酸性 染料の染着によって確認し得た。

2) 好理されたポリエステル纎維の吸湿性が処理によ る結晶化度の增加に伴って增加するという現象を認めた。

3）アミン分解反応が主として結晶周辺の中間領域と 結罩のみだれた部分で行わ机，結晶表面への水分のアク セシビリティが増加すると考察された。

付 記：本咞究は昭和 59 年繊維機械学会北陸支部研 究発表会 $(59.12$ ，金沢)にて発表した。

\section{文献}

1）荒苏賢治，瀻機学誌，36，P-33(1983)

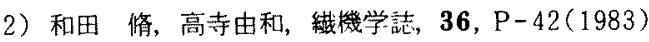

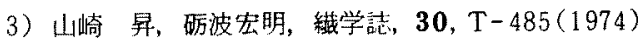

山崎 界，研波宏明，瀻学誌，31，T-241 (1975)

山㱦 昇，砥波宏明，繊学誌，31，T-395(1975)

山崎 昇，砥波宏明，纎学志，32，T-317(1976)

4) 砥波宏明，染色丁業，25，337(1977)

5) W. P. Baker, Jr., J. Polym. Sci., 57, 993 (1962)

6) G. Farrow, D. A. S. Ravens and I. M. Ward, Polymer, 3, 17 (1962)

7）石川欣造編，「被服材料実験書」，同文書院，p. 45 (1982)

8) P. de P. Daubeny, C. W. Bunn and C. J. Brown, Proc. Roy. Soc. (London), A226, 53 (1954) 